\title{
Adpressed tree-fern trunks from the Early Pennsylvanian Joggins Formation of Nova Scotia
}

\author{
HowARD J. FALCON-LANG \\ Department of Earth Sciences, University of Bristol, Bristol BS8 1RJ, U.K. <howard.falcon-lang@bris.ac.uk>
}

Date received: 2 September 2005 Date accepted: 30 September 2005

\begin{abstract}
Tree-fern trunks are among the rarest plant fossils in the Early Pennsylvanian Joggins Formation, with only three specimens recorded, all of which are assigned to Artisophyton. Based on trunk dimensions, these fossils are remains of small trees a few metres high. The facies context is known for only one specimen; this tree grew on a well drained, seasonally dry alluvial plain.

\section{RÉSUMÉ}

Les troncs de fougère arborescente figurent parmi les fossiles végétaux les plus rares à l'intérieur de la Formation du Pennsylvanien précoce de Joggins : on y a seulement relevé trois spécimens, tous classés parmi les Artisophytons. Les dimensions des troncs signalent que ces fossiles constituent des vestiges de petits arbres de quelques mètres de hauteur. On ne connaît le contexte du faciès que dans le cas d'un spécimen : l'arbre en question a grandi dans une pleine alluviale sèche en certaines saisons et bien drainée.
\end{abstract}

[Traduit par la rédaction]

\section{INTRODUCTION}

The Joggins Formation of Nova Scotia contains an outstanding record of Pennsylvanian tropical ecosystems (Davies et al. 2005). Tree-fern trunks are one of the rarest elements of the plant fossil assemblage. Dawson (1868, p. 486) made cryptic reference to erect, but poorly preserved, Caulopteris tree-fern trunks in the Joggins Formation, but gave no morphological description. This record therefore cannot be confirmed. Dawson $(1868$, p. 448, 486) also discovered a second taxon, Megaphyton magnificum, which he described in detail based on a single specimen. This trunk adpression comprised a root mantle from which protruded well preserved, large $(7 \mathrm{~cm}$ diameter), contiguous leaf scars arranged in two rows on either side of the trunk (Fig. 1).

Based on Dawson's drawings (which illustrate the specimen upside down), a deep indentation is evident on the abaxial side of the vascular bundle of all of the leaf scars. Pfefferkorn(1976) erected the morphogenus Artisophyton for adpressed specimens of this type showing indented vascular bundles. As Dawson's morphospecies is based on a specimen that is now believed lost, no attempt is made here to formally transfer Megaphyton magnificum, even though it is clear that his specimen belongs to the morphogenus Artisophyton. Despite Dawson's meticulous approach to geological context(Falcon-Lang and Calder 2005), the stratigraphic position of his specimen is unknown.

Subsequent to Dawson's work, only two additional treefern trunk specimens have been discovered in the Joggins Formation. A second, similarly unprovenanced, specimen was presented to the Fundy Geological Museum, Parrsboro, Nova Scotia (accession number LF-98P-068) by Laing Ferguson in 1998. It is a poorly preserved trunk impression showing eight, large rectangular leaf scars arranged in a single row (Fig. 2A). The vascular traces are difficult to discern, but at least one appears to show abaxial indentation, a diagnostic feature of Artisophyton. A third specimen of Artisophyton was discovered by the author during a Joggins field trip arranged as part of the North American Paleontology Conference, Halifax, Nova Scotia (June 2005). The tree-fern trunk was observed on a metre-sized sandstone block, located near the high-tide mark at the Lower Cove end of the section. It could not be collected as this would have required heavy moving equipment. The purpose of this note is to document the new specimen and discuss its paleoecology. 

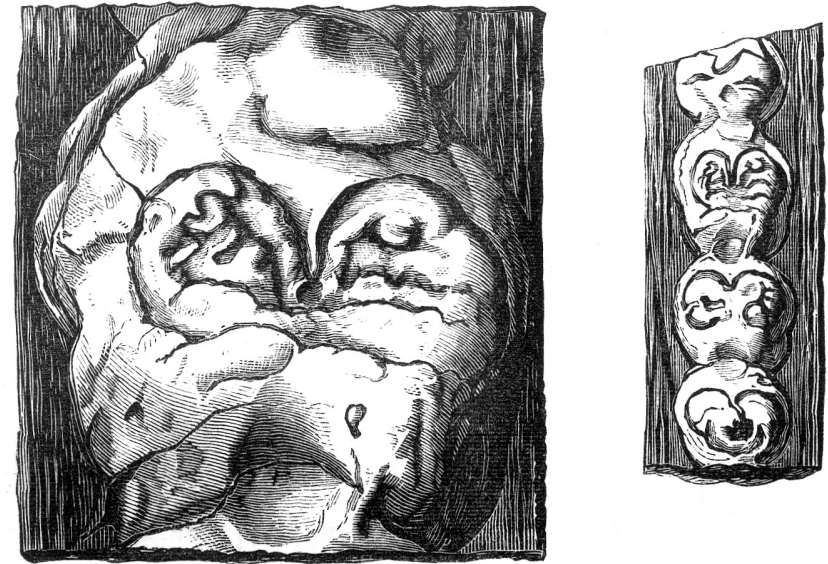

Fig. 1 Dawson's specimen of Artisophyton, which he named Megaphyton magnificum. The specimen is upside down as originally illustrated (Dawson 1868, p. 448, fig. 167B).

\section{NEW TREE-FERN TRUNK SPECIMEN}

The new tree-fern trunk specimen occurs in a multi-storey channel sandstone body within a red mudstone succession (Davies and Gibling 2003), positioned 24-27 $\mathrm{m}$ above the base of the formation (Davies et al. 2005). This unit is interpreted as the deposit of a small paleovalley system incised into a well drained floodplain, and infilled by the deposits of anastomosed river channels (Rygel 2005). These sediments record some of the most continental environments in the Joggins Formation, deposited at a time when the marine coastline lay hundreds of kilometres to the east.

Although a few upright calamiteans are rooted on channel margins, most plant fossils are allochthonous in channel bases. Common calamitean and cordaitalean axes and foliage, the latter locally preserved as charcoal (Falcon-Lang 2003), occur with the tree-fern trunk in an allochthonous assemblage. The trunk adpression ( $9.6 \mathrm{~cm}$ diameter, $56 \mathrm{~cm}$ in length) comprises
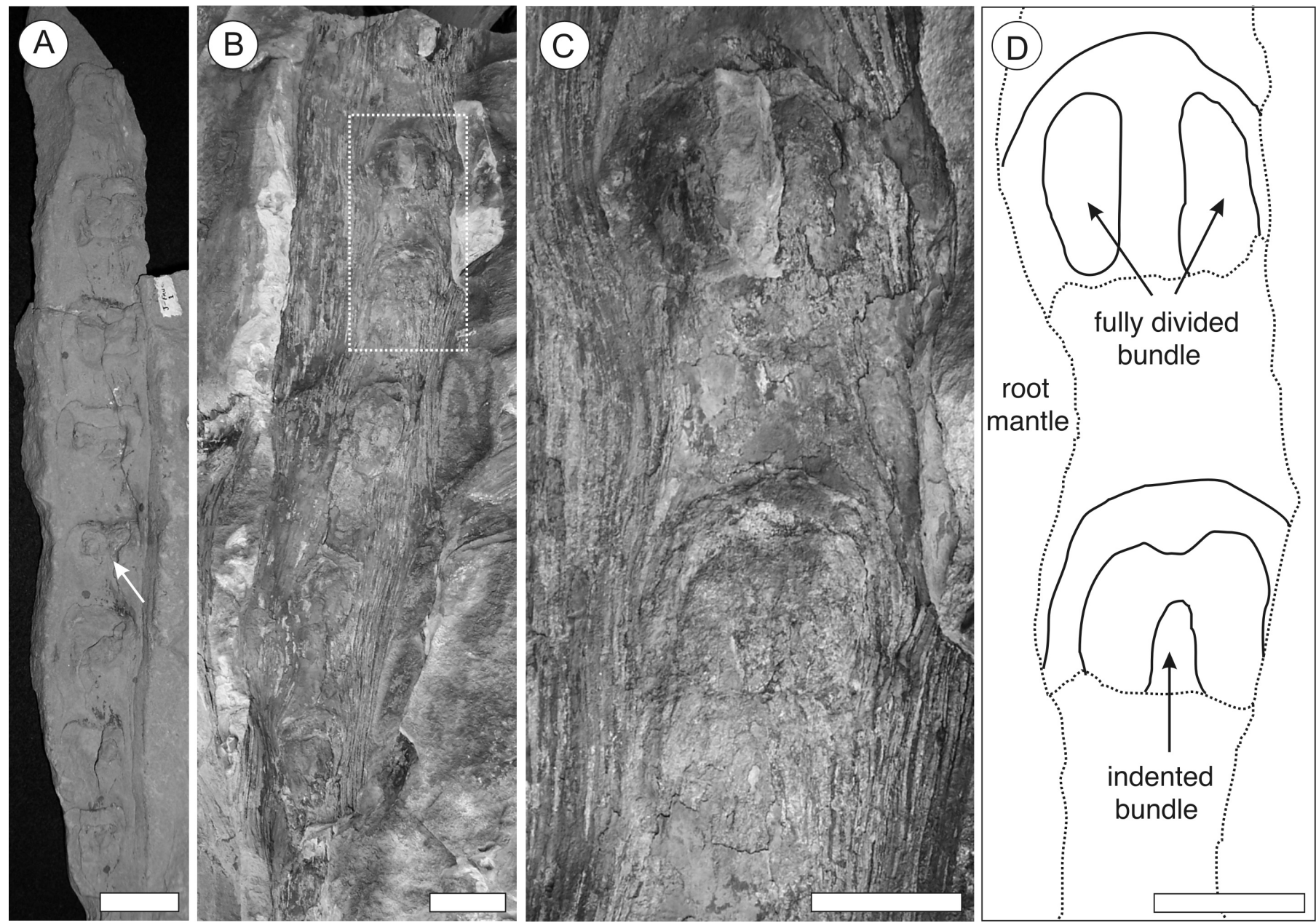

Fig. 2 Artisophyton tree-fern trunk specimens from the Joggins Formation. A. Laing Ferguson's specimen, LF-98P-068, with arrow indicating abaxial indentation; scale $=3 \mathrm{~cm}$. B. New specimen, positioned $24-27 \mathrm{~m}$ above base of the Joggins Formation; boxed area shows enlargement in C; scale $=3 \mathrm{~cm}$. C-D. Detail of leaf scars and interpretation of vascular bundle architecture in the new specimen; scale $=2.5 \mathrm{~cm}$. 
a root mantle from which protrudes seven leaf scars (each 3 $\mathrm{cm}$ high by $5 \mathrm{~cm}$ wide) arranged in a single row, spaced $2-3$ $\mathrm{cm}$ apart (Fig. 2B). The best-preserved leaf scars have a closed outer bundle with a deep indentation on the abaxial side, or are fully divided into two separate closed traces (Fig. 2C-D). These vascular features are not well defined, but there is sufficient detail to classify the specimen as Artisophyton.

\section{PALEOECOLOGY}

Tree ferns evolved in latest Mississippian times and remained rare during the Early Pennsylvanian (DiMichele and Phillips 2002). Based on trunk dimensions, the three Artisophyton specimens from the Joggins Formation were small trees a few metres high (Fig. 3). Artisophyton probably bore foliage of Senftenbergia plumosa or Senftenbergia pennaeformis type (Corsin 1948; Bek and Psenicka 2001). These are among the most common fern foliage types in the Cumberland Group, although their occurrence in the Joggins Formation, in particular, is limited (Bell 1944). According to Pfefferkorn (1976) these tree ferns were not marattialeans, but belonged to the family Schizeaceae or to an extinct lineage, the Tedelaceae. The facies context of the only well provenanced Artisophyton specimen indicates that it grew on a well drained, seasonally dry landscape dominated by fire-prone gymnospermous vegetation (Falcon-Lang 2003).

Little is known of the facies occurrence of early monocyclic tree ferns similar to those of the Joggins Formation. DiMichele

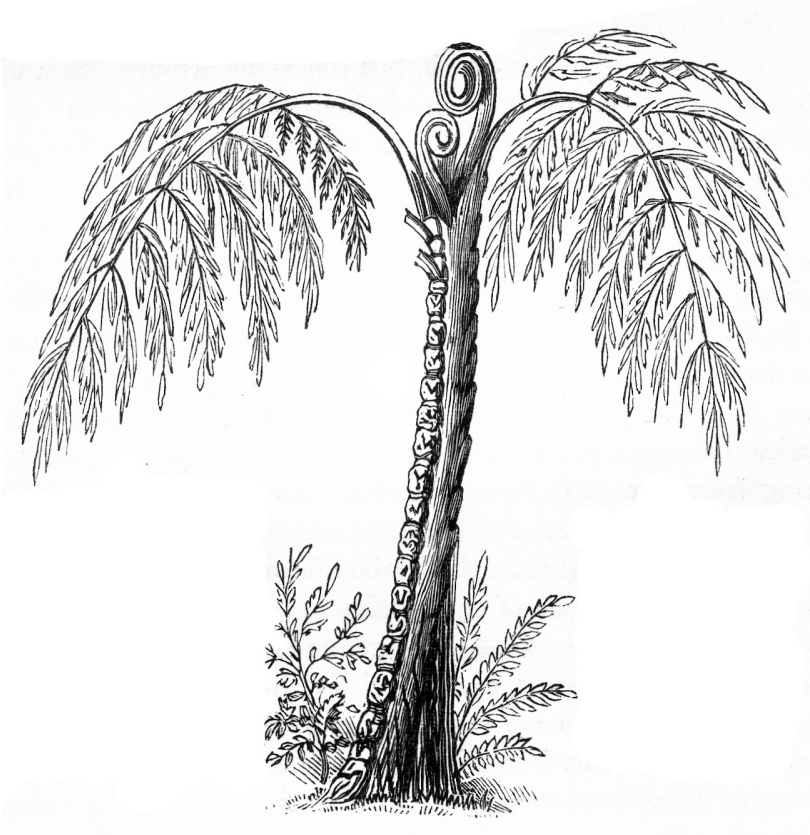

Fig. 3 Dawson's hypothetical whole-plant reconstruction of Artisophyton (Dawson 1868, p. 448, fig. 167A). and Phillips (1977) described the monocyclic Psaronius simplicicaulis from an Early Pennsylvanian bedrock valley-fill succession in Illinois (Leary 1981), where it was associated with an upland/dryland assemblage of cordaitaleans, pteridosperms, and noeggerathialians (Leary 1975, 1993). DiMichele and Phillips (2002) concluded that the tree ferns had occupied poorly drained patches within an otherwise well drained, seasonally dry landscape. A similar ecology is envisaged for the Artisophyton trees based on facies occurrence in the Joggins Formation. This is further supported by the fact that this morphogenus has never been observed in coal balls (Pfefferkorn 1976), indicating its absence from poorly drained peat-forming settings. The new discovery in the Joggins Formation is therefore important, showing that at least two unrelated lineages of arborescent ferns, represented by Psaronius and Artisophyton, colonized dry environments in Early Pennsylvanian times.

\section{ACKNOWLEDGEMENTS}

I acknowledge receipt of a NERC Fellowship (NER/I/S/2001/ 00738) held at the University of Bristol. I thank John Calder for alerting me to the existence of Laing Ferguson's specimen, and Ken Adams and Kathy Goodwin of the Fundy Geological Museum for facilitating its access. Arden Bashforth and Chris Cleal are thanked for their constructive reviews, and Rob Fensome for editorial work.

\section{REFERENCES}

Bek. J., \& Psenicka, J. 2001. Senftenbergia plumosa (Artis) emend. and its spores from the Carboniferous of the Kladno and Pilsen Basins, Bohemian Massif, and some related and synonymous taxa. Review of Palaeobotany and Palynology, 116, pp. 213-232.

BELL, W.A. 1944. Carboniferous rocks and fossil floras of northern Nova Scotia. Geological Survey of Canada Memoir 238, 120 p.

Consin, P. 1948. Reconstitutions de pécoptéridées: genres Caulopteris Lindley and Hutton, Megaphyton Artis et Hagiophyton nov. gen. Annales du Société Géologique du Nord, 67, pp. 6-25.

Davies, S.J., \& Gibling, M.R. 2003. Architecture of coastal and alluvial deposits in an extensional basin: the Carboniferous Joggins Formation of eastern Canada. Sedimentology, 50, pp. 415-439.

Davies, S.J., Gibling, M.R., Rygel, M.C., \& Calder, J.H. 2005. The Pennsylvanian Joggins Formation of Nova Scotia: sedimentological log and stratigraphic framework of the historic fossil cliffs. Atlantic Geology, 41, pp. 115-142.

Dawson, J.W. 1868. Acadian geology. The geological structure, organic remains, and mineral resources of Nova Scotia, New Brunswick, and Prince Edward Island. $2^{\text {nd }}$ Edition. Macmillan, London, $694 \mathrm{p}$. 
DiMichele, W.A., \& Phillips, T.L. 1977. Monocylic Psaronius from the Lower Pennsylvanian of the Illinois Basin. Canadian Journal of Botany, 55, pp. 2514-2524.

DiMichele, W.A., \& Phillips, T.L. 2002. The ecology of Paleozoic ferns. Review of Palaeobotany and Palynology, 119, pp. 143-159.

FALCON-LANG, H.J. 2003. Late Carboniferous tropical dryland vegetation in an alluvial plain setting, Joggins, Nova Scotia, Canada. Palaios, 18, pp. 197-211.

FALCON-LANG, H.J., \& CALDER, J.H. 2005. Sir William Dawson (1820-1899): a very modern paleobotantist. Atlantic Geology, 41, pp. 103-114.

LEARY, R.E. 1975. Early Pennsylvanian paleogeography of an upland area, western Illinois, USA. Bulletin de la Société Géologique de Belgique, 84, pp. 19-31.
LEARY, R.E. 1981. Early Pennsylvanian geology and paleobotany of the Rock Island County, Illinois. Part 1: Geology. Illinois State Museum, Report of Investigations, 37, 88 p.

LEARY, R.E. 1993. Enigmatic fossil plants from the Early Pennsylvanian of western Illinois. Transactions of the Illinois State Academy of Sciences, 86, pp. 119-125.

Pfefferkorn, H.W. 1976. Pennsylvanian tree-fern compressions Caulopteris, Megaphyton, and Artisophyton gen. nov. in Illinois. Illinois State Geological Survey Circular 492, 31 p. RygeL, M.C. 2005. Alluvial sedimentology and basin analysis of Carboniferous strata near Joggins, Nova Scotia, Atlantic Canada. Unpublished Ph.D. thesis, Dalhousie University, Halifax, Nova Scotia, 468 p.

Editorial responsibility: Robert A. Fensome 